УДК 334.732 .2

DOI: https://doi.org/10.37320/2415-3583/12.31

Булюк В.В. доктор економічних наук, професор, Херсонський національний технічний університет

\title{
ОЦІНОЧНІ ХАРАКТЕРИСТИКИ СТАНУ РОЗВИТКУ КРЕДИТНИХ СПІЛОК В УКРӒ̈НІ
}

Кредитні спілки є невід'ємною складовою частиною фінансової системи країни з ринковою економікою. Їх основною функиією є надання депозитно-кредитних та інших супутніх фінансових послуг фізичним особам, дрібним селянським та фермерським господарствам, а також мікропідприємствам, кредитування яких є нецікавим для банків. Стрімкий розвиток кредитних спілок в Украйні розпочався з набуттям Украӥною незалежності й базувався на відносно розвиненій споживчій кооперачії. Перед початком світової фінансової кризи в Україні налічувались 829 кредитних спілок. 3 початком кризи як кількість кредитних спілок, так $i$ показники їх діяльності почали стрімко зменшуватись, і ией процес продовжується досі. Однак кількісні показники діяльності кредитних спілок, розраховані на одну спілку та одного члена спілки, мали більш стійку та навіть позитивну динаміку. Це дає підстави стверджувати, що фінансова криза привела до банкрутства фінансово нестійких, $з$ низьким рівнем менеджменту та таких, щьо порушували принщипи кооперативного руху, кредитних спілок. Кредитні спілки, щзо залишилися, є основою розвитку кредитних спілок в Украӥні.

Ключові слова: небанківські кредитно-фінансові установи, кредитні спілки, активи кредитних спілок України, капітал кредитних спілок України, світова фінансова криза.

Постановка проблеми. Світовий досвід економічно розвинених країн підтверджує, що одним із базових елементів їх економічної системи $є$ розгалужена, добре структурована фінансова система, в якій разом із банками, які, як правило, є провідними уні- версальними кредитними установами, функціонує розгалужена мережа спеціалізованих небанківських фінансово-кредитних установ. При цьому кожна така установа функціонує на певному сегменті фінансового ринку країни, забезпечуючи якісними фінансовими 
послугами окремі сектори економіки, які мають свої специфічні риси діяльності і самі набувають певних специфічних особливостей у своїй діяльності. Разом з іншими до таких спеціалізованих фінансово-кредитних установ можна віднести кредитні спілки.

Первинним призначенням кредитних спілок у процесі набуття ними сучасних, цивілізаційних якостей у середині XIX сторіччя було забезпечення дрібного та середнього селянства Свропи кредитними ресурсами, які забезпечували їм вихід на європейський ринок сільськогосподарської продукції.

Як усякі життєздатні установи, кредитні спілки розвивалися разом із продуктивними силами та відповідними суспільними відносинами. Розширювалась сфера й зростали масштаби їх діяльності а також кількість та якість фінансових та інших видів супутніх послуг.

Нині в економічно розвинених економіках Європи кредитні спілки відіграють важливу роль у забезпеченні дрібних сільгоспвиробників як кредитними ресурсами, так і супутніми фінансовими послугами, що забезпечує стабільність їх діяльності та відіграє важливу роль у структурі небанківських кредитнофінансових установ.

Враховуючи світовий досвід, можемо стверджувати, що розвиток кредитних спілок в Україні допоможе сформувати таку фінансово-кредитну систему, яка буде сприяти динамічному розвитку як сільського господарства зокрема, так і економіки України загалом.

Аналіз останніх досліджень і публікацій. Проблемам становлення та розвитку кредитних спілок в Україні приділяли значну увагу вітчизняні науковці, зокрема Ж.Д. Анпілогов, М.Д. Бедринець, Н.I. Версаль, О.Д. Вовчак, С.В. Герасимова, В.В. Гончаренко, О.Л. Климко, О.І. Гриценко, Б.А. Дадашев.

Мета статті полягає в оцінюванні показників розвитку кредитних спілок в Україні та виявленні проблем у цьому процесі.

Виклад основного матеріалу. Розвиток кредитних спілок у незалежній Україні базувався на вже наявній системі сільської споживчої кооперації, забезпечення якої фінансовими ресурсами спонукало дрібних товаровиробників до створення власних кредитно-фінансових установ, якими були кредитні спілки. Правову основу функціонування кредитних спілок в Україні було закладено прийняттям у 1992 році Законом України «Про об’єднання громадян» [1]. 20 вересня 1993 року Указом Президента України було затверджено «Тимчасове положення про кредитні спілки в Україні», чим було закріплено статус кредитних спілок у фінансовій системі України [2]. Незважаючи на досить значний термін функціонування кредитних спілок в Україні, вони ще не набули необхідного статусу та ваги у фінансово-кредитній системі України. У зв'язку з цим проаналізуємо динаміку основних показників діяльності кредитних спілок за 2012-2019 роки (табл. 1).

Дані табл. 1 показують, що за 2012-2019 роки, за винятком 2013 року, кількість кредитних спілок в Україні неухильно знижувалась: якщо у 2012 році у Державному реєстрі фінансових установ Національної комісії, що здійснює державне регулювання у сфері ринків фінансових послуг [2], було зареєстровано 617 кредитних спілок, то на кінець 2019 року їх стало 348, тобто 56\% рівня 2012 року, при цьому динаміка скорочення кількості спілок за досліджуваний період була вкрай нерівномірною. Так, у 2013 році порівняно з 2012 роком їх кількість зросла на 7 одиниць, але у 2014 та 2015 роках порівняно з попереднім періодом зменшилась на 35 та 1 одиницю відповідно. У 2016 та 2017 роках відбулося найбільш масове зменшення кількості спілок: на 126 та 84 одиниці відповідно. Впродовж 2018 та 2019 років темпи скорочення знизилися, склавши 20 та 10 одиниць відповідно.

Необхідно зауважити, що за даними Національної комісії, що здійснює державне регулювання у сфері ринків фінансових послуг, у 2008 році, тобто перед початком світової фінансової кризи, в Україні було зареєстровано 829 кредитних спілок, а впродовж наступних трьох років їх кількість зменшувалась, до 613 одиниць у 2011 році. Впродовж 2012 та 2013 років кількість спілок незначно зросла, а саме до 624 одиниць, а в подальшому, як показують дані табл. 1, знижувалась.

Відповідно, можна зробити висновок, що діяльність кредитних спілок, зокрема їх кількість, тісно пов'язана зі стабільністю фінансової системи України, оскільки зменшення їх кількості тісно корелює 3 негараздами в економіці, зокрема світовою фінансовою кризою, та політичними й економічними негараздами, які розпочалися в Україні у 2014 році.

Кількість членів, які брали участь у діяльності кредитних спілок, за досліджуваний період мала більш стійку, однак негативну динаміку, зокрема у 2008 році, тобто на початку світової фінансової кризи, членами кредитних спілок в Україні були 2 669,4 тис. осіб. У всі наступні роки, за винятком 2012 року, кількість членів неухильно знижувалась, а на кінець 2019 року складала 465,2 тис. осіб, тобто зниження склало майже шість разів. При цьому якщо у 2008 році одна кредитна спілка мала 3,2 тис. членів, то на кінець 2019 року їх кількість зменшилась до 1,3 членів. Слід зауважити, що кількість членів у розрахунку на 1 кредитну спілку скорочувалась із 2008 року по 2010 рік: з 3,2 тис. членів, до 2,1 тис. членів відповідно. 32011 року середня кількість членів однієї спілки відносно стабілізувалась і коливалась за досліджуваний період від 1,8 тис. членів у 2012 році, до 1,3 тис. членів у 2015 році.

Відповідно, можна зробити висновок, що зменшення кількості кредитних спілок супроводжувалось як їх банкрутством, так й іншими негативними процесами, які в результаті привели до втрати привабливості кредитних спілок як надійних фінансових установ i сприяли переходу їх членів на депозитно-кредитне обслуговування до інших кредитно-фінансових установ, перш за все банків.

Сума загальних активів кредитних спілок в Україні за досліджуваний період мала змінну динаміку. Так, на кінець 2008 року їх загальна сума складала 6 064,9 млн. грн., однак із початком негативних явищ, пов'язаних зі світовою фінансовою кризою, почала стрімко скорочуватись, а на кінець 2016 року досягла 2 032,5 млн. грн., що складало 33,5\% рівня 2008 року. 32017 року сума активів кредитних спілок почала повільно зростати, а на кінець 2019 року досягла рівня 2441,1 млн. грн., тобто порівняно з 2016 роком зростання склало 20,1\%, однак так і не досягла докризового рівня. 
Таблиця 1 - Динаміка основних показників діяльності кредитних спілок в Україні за 2012-2019 роки

\begin{tabular}{|c|c|c|c|c|c|c|c|}
\hline \multirow[b]{2}{*}{ Показник } & \multirow{2}{*}{$\begin{array}{c}2012 \text { рік } \\
\text { кількість }\end{array}$} & \multicolumn{2}{|c|}{2013 рік } & \multicolumn{2}{|c|}{2014 рік } & \multicolumn{2}{|c|}{2015 рік } \\
\hline & & кількість & $\begin{array}{c}\text { відхилення, } \\
\text { \% }\end{array}$ & кількість & $\begin{array}{c}\text { відхилення, } \\
\%\end{array}$ & кількість & $\begin{array}{c}\text { відхилення, } \\
\%\end{array}$ \\
\hline $\begin{array}{l}\text { Кількість } \\
\text { зареєстрованих } \\
\text { кредитних спілок } \\
\text { (на кінець періоду) } \\
\end{array}$ & 617 & 624 & 101 & 589 & 94 & 588 & 100 \\
\hline $\begin{array}{l}\text { Кількість членів } \\
\text { КС, тис. осіб }\end{array}$ & 1095,9 & 980,9 & 90 & 821,6 & 84 & 764,6 & 93 \\
\hline Активи, млн. грн. & 2656,9 & 2598,8 & 98 & 2338,7 & 90 & 2064,3 & 88 \\
\hline Капітал, млн. грн. & 1088,7 & 1055,6 & 97 & 1048,7 & 99 & 1040,9 & 99 \\
\hline $\begin{array}{l}\text { Дохід КС, } \\
\text { млн. грн. }\end{array}$ & 755,1 & 764,6 & 101 & 692,1 & 91 & 633,4 & 92 \\
\hline $\begin{array}{l}\text { Витрати КС, } \\
\text { млн. грн. }\end{array}$ & 625,8 & 665,3 & 106 & 621,1 & 93 & 610,3 & 98 \\
\hline $\begin{array}{l}\text { Нерозподілений } \\
\text { дохід (непокритий } \\
\text { збиток), млн. грн. }\end{array}$ & 67,7 & $-8,2$ & -12 & $-10,1$ & 123 & $-28,1$ & 278 \\
\hline
\end{tabular}

\begin{tabular}{|c|c|c|c|c|c|c|c|c|}
\hline \multirow[b]{2}{*}{ Показник } & \multicolumn{2}{|c|}{2016 рік } & \multicolumn{2}{|c|}{2017 рік } & \multicolumn{2}{|c|}{2018 рік } & \multicolumn{2}{|c|}{2019 рік } \\
\hline & кількість & $\begin{array}{c}\text { відхилення, } \\
\text { \% }\end{array}$ & кількість & $\begin{array}{c}\text { відхилення, } \\
\text { \% }\end{array}$ & кількість & $\begin{array}{c}\text { відхилення, } \\
\text { \% }\end{array}$ & кількість & $\begin{array}{c}\text { відхилення, } \\
\text { \% }\end{array}$ \\
\hline $\begin{array}{l}\text { Кількість } \\
\text { зареєстрованих } \\
\text { кредитних } \\
\text { спілок (на кінець } \\
\text { періоду) }\end{array}$ & 462 & 79 & 378 & 82 & 358 & 95 & 348 & 97 \\
\hline $\begin{array}{l}\text { Кількість членів } \\
\text { КС, тис. осіб }\end{array}$ & 642,9 & 84 & 564,1 & 88 & 479 & 85 & 465,2 & 97 \\
\hline Активи, млн. грн. & 2032,5 & 98 & 2169,8 & 107 & 2218,4 & 102 & 2441,1 & 110 \\
\hline $\begin{array}{l}\text { Капітал, } \\
\text { млн. грн. }\end{array}$ & 1044,4 & 100 & 1062,5 & 102 & 977,1 & 92 & 1106,1 & 113 \\
\hline $\begin{array}{l}\text { Дохід КС, } \\
\text { млн. грн. }\end{array}$ & 715,6 & 113 & 739,1 & 103 & 798,5 & 108 & 644,8 & 81 \\
\hline $\begin{array}{l}\text { Витрати КС, } \\
\text { млн. грн. }\end{array}$ & 618,3 & 101 & 659,6 & 107 & 747,5 & 113 & 564,2 & 75 \\
\hline $\begin{array}{l}\text { Нерозподілений } \\
\text { дохід } \\
\text { (непокритий } \\
\text { збиток), млн. грн. }\end{array}$ & 76,7 & -273 & 117,9 & 154 & 113,8 & 97 & 158 & 139 \\
\hline
\end{tabular}

Джерело: складено автором за даними джерела [6]

Сума загальних активів у розрахунку на 1 кредитну спілку у 2008 році складала 7,3 млн. грн. 32008 року вона почала знижуватись, а на кінець 2015 року складала 3,5 млн. грн., однак із 2016 року активи кредитних спілок в Україні почали зростати, досягши на кінець 2019 року 7,0 млн. грн. у розрахунку на одну кредитну спілку, що майже дорівнювало рівню 2008 року.

Загалом можна зробити висновок, що світова фінансова криза справила суттєвий негативний вплив на діяльність кредитних спілок в Україні, в результаті якого навіть через десять років діяльності після початку кризи їх сумарні активи складали лише 40,2\% рівня 2008 року, а сума активів в розрахунку на одну кредитну спілку лише досягла докризового рівня.

Оцінюючи динаміку капіталу кредитних спілок України, маємо зробити висновок, що загальна його сума від 2008 року досить суттєво коливалась. Так, якщо у 2008 році загальна сума капіталу кредитних спілок складала 1 714,0 млн. грн., то вже на кінець 2009 року під впливом світової фінансової кризи вона зменшилась до 765,8 млн. грн., що склало 44,7\% рівня 2008 року. У 2010 році капітал кредитних спілок незначно зріс, а саме до 1 117,3 млн. грн., однак у 2011 році він знову знизився до 942,9 млн. грн. На кінець 2019 року загальна сума капіталу кредитних спілок України складала 1 106,1 млн. грн., що складало 64,5\% рівня 2008 року. Загалом якщо оцінювати зміну загальної суми капіталу кредитних спілок, то можна сказати, що без урахування передкризового 2008 року та першого післякризового 2009 року вона коливалась від 942,9 млн. грн. у 2011 році до 1 117,3 млн. грн. у 2010 році, тобто коливання відбувалося в межах близько $15 \%$.

Якщо оцінювати суму капіталу кредитних спілок у розрахунку на 1 спілку, то можна зробити висновок, що з початком світової фінансової кризи їх сума різко зменшилася 32067 млн. грн. у 2008 році до 1014 млн. грн. у 2009 році. Однак в наступні роки сума капіталу 3 незначними коливаннями неухильно зростала, у 2016 році вона досягла рівня 2008 року, а на кінець 2019 року становила 3178 млн. грн., що скла- 
дало $153,7 \%$ загальної суми капіталу кредитних спілок у розрахунку на одну спілку порівняно з 2008 роком.

Аналіз суми капіталу кредитних спілок у розрахунку на одного члена показує більш позитивні результати, зокрема якщо у 2008 році ця сума складала 642 грн., то у 2009 році - тільки 349 грн., що складало 54,4\% рівня 2008 року. Однак уже у 2010 році вона складала 711 гривень, що більше, ніж у докризовий 2008 рік. Всі наступні роки аналізованого періоду ця сума зростала, а на кінець 2019 року досягла 2377 гривень.

Отже, загалом після світової фінансової кризи загальна сума капіталу кредитних спілок України залишалася відносно незмінною, однак структурні зміни кількості кредитних спілок та кількості їх членів привели до того, що сума капіталу в розрахунку на одну спілку та одного члена кредитної спілки зростали, навіть перевищували докризовий рівень.

Хоча діяльність кредитних спілок і не спрямована на отримання прибутку, дані табл. 1 показують, що ефективність їх діяльності, яку можна оцінити за результатами прибутковості їх діяльності, була досить нестабільною, а на отримані результати суттєво впливала політична та економічна ситуація в Україні. Зокрема, у 2012 році система кредитних спілок України отримала 67,7 млн. грн. прибутку, за 2013-2015 роки кредитні спілки в Україні отримували збитки, від 2016 року до кінця досліджуваного періоду вони знову працювали 3 прибутком, причому загальна сума прибутку постійно зростала: із 76,7 млн. грн. у 2016 році до 158,0 млн. грн. у кінці 2019 року.

Висновки. Проведений аналіз діяльності кредитних спілок в Україні показав, що радикально негативний вплив на кількісні та якісні показники іх функціонування справила світова фінансова криза. Вона показала, що ліберальна кредитна політика, яка була панівною до 2008 року у фінансово-кредитному секторі економіки практично всіх країн і всіх видів фінансово-кредитних установ, яка проявлялась у необгрунтованому, занадто ризикованому, спрямованому на розширення масштабів, проведення кредитних операцій, виявилася хибною. В результаті це привело до значних обсягів неповернення позик і негативно вплинуло на ліквідність практично всіх кредитно-фінансових установ, зокрема кредитних спілок в Україні, що в подальшому привело до їх банкрутства. Отже, кількісні показники діяльності кредитних спілок виявилися негативними, що проявилося у зменшенні їх кількості, кількості їх членів, загальної суми їх активів та капіталу.

Однак кількісні показники, розраховані на одну спілку та на одного члена кредитної спілки, особливо стосовно капіталу, та загальної суми отриманого прибутку показали, що загалом система кредитних спілок в Україні пережила кризові явища й відносно успішно розвивається.

Крім того, позитивним наслідком світової фінансової кризи для кредитних спілок в Україні можна вважати те, що з ринку пішли фінансово слабкі, з низьким рівнем менеджменту кредитні спілки, які проводили ризикову кредитну політику та нехтували загальними принципами кооперативного руху.

Негативним наслідком їх діяльності на фінансовому ринку України стало те, що вони підірвали довіру потенційних учасників до кредитних спілок як надійних небанківських кредитно-фінансових установ.

\section{Список використаних джерел:}

1. Про об’єднання громадян : Закон України від 16 червня 1992 року № 2460-XII. URL: https://zakon.rada.gov.ua/laws/ show/2460-12 (дата звернення: 11.05.2020).

2. Про Тимчасове положення про кредитні спілки в Україні : Указ Президента України від 20 вересня 1993 року № $377 / 93$. URL: https://zakon.rada.gov.ua/laws/show/377/93 (дата звернення: 11.05.2020).

3. Про кредитні спілки : Закон України від 20 грудня 2001 року № 2908-III. URL: https://zakon.rada.gov.ua/laws/show/2908-14 (дата звернення: 11.05.2020).

4. Дадашев Б.А., Гриценко О.І. Кредитні спілки в Україні : навчальний посібник. Суми : ДВНЗ «УАБС НБУ», 2011. 196 с.

5. Шкварчук Л.О., Цікайло М.А. Аналіз діяльності кредитних спілок на ринку фінансових послуг України. Вісник Національного університету «Львівська політехніка». Логістика. 2014. № 811. C. 422-425. URL: http://nbuv.gov.ua/UJRN/ VNULPL_2014_811_63 (дата звернення: 11.05.2020).

6. Інформація про стан і розвиток кредитних установ України // Офіційний сайт Національної комісії, що здійснює державне регулювання у сфері ринків фінансових послуг. URL: https://www.nfp.gov.ua/ua/Informatsiia-pro-stan-i-rozvytokkredytnykh-ustanov-Ukrainy.html (дата звернення: 11.05.2020).

\section{References:}

1. Pro ob’jednannja ghromadjan : Zakon Ukrajiny vid 16 chervnja 1992 roku № 2460-XII. URL: https://zakon.rada.gov.ua/laws/ show/2460-12 (accessed: 11 May 2020).

2. Pro Tymchasove polozhennja pro kredytni spilky v Ukrajini : Ukaz Prezydenta Ukrajiny vid 20 veresnja 1993 roku № $377 / 93$. URL: https://zakon.rada.gov.ua/laws/show/377/93 (accessed: 11 May 2020).

3. Pro kredytni spilky : Zakon Ukrajiny vid 20 ghrudnja 2001 roku № 2908-III. URL: https://zakon.rada.gov.ua/laws/show/2908-14 (accessed: 11 May 2020).

4. Dadashev B.A., Ghrycenko O.I. (2011) Kredytni spilky v Ukrajini : navchaljnyj posibnyk. Sumy : DVNZ "UABS NBU".

5. Shkvarchuk L.O., Cikajlo M.A. (2014) Analiz dijaljnosti kredytnykh spilok na rynku finansovykh poslugh Ukrajiny. Visnyk Nacionaljnogho universytetu "Ljvivsjka politekhnika". Loghistyka, no. 811, pp. 422-425. URL: http://nbuv.gov.ua/UJRN/ VNULPL 201481163 (accessed 11 May 2020).

6. Informacija pro stan i rozvytok kredytnykh ustanov Ukrajiny. Oficijnyj sajt Nacionaljnoji komisiji, shho zdijsnjuje derzhavne reghuljuvannja u sferi rynkiv finansovykh poslugh. URL: https://www.nfp.gov.ua/ua/Informatsiia-pro-stan-i-rozvytok-kredytnykhustanov-Ukrainy.html (accessed 11 May 2020). 
Bulyuk Vitaly

Kherson National Technical University

\section{EVALUATION CHARACTERISTICS OF THE STATE OF DEVELOPMENT OF CREDIT UNIONS IN UKRAINE}

World experience shows that credit unions are an important component of the financial and credit systems of market economies. Historically, in their modern form, credit unions emerged in the mid-nineteenth century as financial institutions that provided deposit and credit services to small and medium-sized farms. Later, in the process of their evolutionary development, they expanded the scope of their activities and began to provide small loans and related financial services to individuals and small businesses that were uninteresting to banking institutions. The development of credit unions in Ukraine began at the same time as Ukraine gained political independence, and was based on the already existing system of credit cooperation in Ukraine, which required financial resources but did not have wide access to bank loans. The rapid development of credit unions led to the fact that at the end of $2008,829 \mathrm{credit}$ unions were registered in the State Register of Financial Institutions of the National Commission for State Regulation of Financial Services Markets. However, the global financial crisis has led to a sharp decline in the number of credit unions in Ukraine, and this process continues to this day. Along with the decrease in the number of credit unions, other quantitative indicators of their activity began to decrease, in particular the number of credit union members, the total amount of assets, the capital of credit unions, the income received, and so on. However, quantitative indicators per credit union and one credit union member show that after a sharp decline, immediately after the global financial crisis, they stabilized and became more stable, i.e. periods of decline were accompanied by periods of growth, and some indicators showed positive dynamics. This primarily concerned the amount of capital per credit union and one member of a credit union. Such dynamics of quantitative indicators per one credit union and per one member of the credit union, in our opinion, indicates that as a result of the crisis in Ukraine's economy, which were provoked by the global financial crisis, the credit union sector was cleansed of financially weak ones with risky credit policy, and those credit unions that violated the basic principles of the cooperative movement. Their unprofessional activities in the financial services market have caused significant damage to both the cooperative movement in general and credit unions in particular. However, as a result of their bankruptcy, only financially stable, reliable credit unions remained on the market, which will become the basis for the development of the cooperative movement in Ukraine.

Key words: non-bank credit and financial institutions, credit unions, credit unions' assets of Ukraine, credit unions' capital of Ukraine, global financial crisis.

JEL classification: G23 